\title{
Janibacter melonis sp. nov., isolated from abnormally spoiled oriental melon in Korea
}

Correspondence Jung-Hoon Yoon jhyoon@kribb.re.kr

\author{
Jung-Hoon Yoon, ${ }^{1}$ Hyang Burm Lee, ${ }^{2}$ Soo-Hwan Yeo $^{3}$ and Jae-Eul Choi ${ }^{4}$ \\ ${ }^{1}$ Korea Research Institute of Bioscience and Biotechnology (KRIBB), PO Box 115, Yusong, \\ Taejon, Korea \\ ${ }^{2}$ School of Biological Sciences, Seoul National University, Kwanak-gu, Seoul 151-742, Korea \\ ${ }^{3}$ The Center for Traditional Microorganism Resources, Keimyung University, Shindang-Dong, \\ Dalseo-gu, Daegu, Korea \\ ${ }^{4}$ Department of Crop Science, Chungnam National University, Yusong, Taejon, Korea
}

The genus Janibacter was proposed by Martin et al. (1997) with a single species, Janibacter limosus. Subsequently, two further species, Janibacter terrae (Yoon et al., 2000) and Janibacter brevis (Imamura et al., 2000), have been described. However, J. brevis has recently been recognized as a later heterotypic synonym of J. terrae (Lang et al., 2003). All Janibacter species have been isolated from environmentally polluted samples. In this study, we describe two strains, $\mathrm{CM} 2104^{\mathrm{T}}$ and CM2110, which were isolated from the inner part of abnormally spoiled oriental melon (Cucumis melo) in Korea. These isolates were considered to be Janibacter-like strains based on 16S rRNA gene sequence comparison. Accordingly, the aim of the present study was to determine

Published online ahead of print on 17 September 2004 as DOI 10.1099/ijs.0.63167-0.

Abbreviations: FAME, fatty acid methyl ester; TEM, transmission electron microscopy.

The GenBank/EMBL/DDBJ accession numbers for the 16S rRNA gene sequences of strains $C M 2104^{\top}$ and $C M 2110$ are AY522568 and AY522569, respectively. the exact taxonomic positions of strains $\mathrm{CM} 2104^{\mathrm{T}}$ and CM2110 with a combination of phenotypic typing, detailed phylogenetic analysis based on 16S rRNA gene sequence analysis and genomic relatedness.

Abnormally spoiled oriental melon collected from a cultivation field was used as the source for isolation of endophytic bacteria. Strains $\mathrm{CM} 2104^{\mathrm{T}}$ and CM2110 were isolated by a standard dilution plating technique on nutrient agar (NA; Difco) at $30^{\circ} \mathrm{C}$. The strains were cultivated on rich (R) medium (Martin et al., 1997) or brain heart infusion (BHI) medium at $30{ }^{\circ} \mathrm{C}$ to investigate their morphological and physiological characteristics. Cell mass for analyses of the cell wall, menaquinones and polar lipids and for DNA extraction was obtained after cultivation for 2 days in liquid $\mathrm{R}$ medium at $30^{\circ} \mathrm{C}$. Reference strains included J. limosus DSM $11140^{\mathrm{T}}$ and J. terrae KCCM $80001^{\mathrm{T}}$. For fatty acid methyl ester (FAME) analysis, cell mass of strains $\mathrm{CM} 2104^{\mathrm{T}}$ and CM2110 was obtained from agar plates after cultivation for 7 days at $30^{\circ} \mathrm{C}$ on solid $\mathrm{R}$ medium and trypticase soy agar (TSA; Difco). Cell morphology was 
examined by light microscopy (Nikon E600) and transmission electron microscopy (TEM). The presence of flagella was examined by TEM using cells from exponentially growing cultures. Growth at various temperatures and various $\mathrm{NaCl}$ concentrations was measured in liquid $\mathrm{R}$ and BHI media. Growth under anaerobic conditions was determined in an anaerobic chamber with anaerobically prepared $\mathrm{R}$ agar. Oxidase activity was determined by using $1 \%(\mathrm{w} / \mathrm{v})$ p-aminodimethylaniline oxalate. Catalase activity was determined by bubble production in a $3 \%(\mathrm{v} / \mathrm{v})$ hydrogen peroxide solution. Hydrolysis of aesculin, $\mathrm{H}_{2} \mathrm{~S}$ production, methyl-red and Voges-Proskauer reactions, and nitrate reduction were determined as described by Lanyi (1987). Hydrolysis of casein, gelatin, hypoxanthine, starch, Tween 80, tyrosine, urea and xanthine was determined as described by Cowan \& Steel (1965). Utilization of various substrates as sole carbon and energy sources was determined as described by Gordon \& Mihm (1957). Acid production from carbohydrates was determined according to Hugh \& Leifson (1953). Other physiological tests were performed with the API 20E system (bioMérieux).

The isomer type of the diamino acid in the cell-wall peptidoglycan was analysed using TLC according to the method described by Komagata \& Suzuki (1987). Menaquinones were analysed as described by Komagata \& Suzuki (1987), using reversed-phase HPLC. For quantitative analysis of the cellular fatty acid composition, a loop of cell mass was harvested and FAMEs were extracted and prepared according to the standard protocol of the MIDI/Hewlett Packard Microbial Identification System (Sasser, 1990). Polar lipids were extracted using the procedures described by Minnikin et al. (1984) and identified by two-dimensional TLC followed by spraying with appropriate detection reagents (Komagata \& Suzuki, 1987). Chromosomal DNA was isolated and purified according to the method described previously (Yoon et al., 1996), with the exception that ribonuclease $\mathrm{T} 1$ was used together with ribonuclease $\mathrm{A}$. The DNA G + C content was determined by the method of Tamaoka \& Komagata (1984). DNA was hydrolysed and the resultant nucleotides were analysed by reversed-phase HPLC.

$16 \mathrm{~S}$ rRNA genes were amplified by PCR using two universal primers as described previously (Yoon et al., 1998). Sequencing of the amplified 16S rRNA gene was performed as described by Yoon et al. (2003). Alignment of sequences was carried out with CLUSTAL W software (Thompson et al., 1994). Gaps at the $5^{\prime}$ and $3^{\prime}$ ends of the alignment were omitted from further analysis. Phylogenetic trees were inferred using three tree-making algorithms, the neighbour-joining (Saitou \& Nei, 1987), maximumlikelihood (Felsenstein, 1981) and maximum-parsimony (Kluge \& Farris, 1969) methods in the PHYLIP package (Felsenstein, 1993). Evolutionary distance matrices for the neighbour-joining method were calculated with the algorithm of Jukes \& Cantor (1969) with the DNADIST program. The stability of relationships was assessed by a bootstrap analysis based on 1000 resamplings of the neighbourjoining dataset using the programs SEQBOOT, DNADIST, NEIGHBOR and CONSENSE of the PHYLIP package. DNADNA hybridization was performed fluorometrically by the method of Ezaki et al. (1989) using photobiotin-labelled DNA probes and microdilution wells. Hybridization was performed with five replications for each sample. Of the values obtained, the highest and lowest values for each sample were excluded; DNA-DNA relatedness values are the mean of the remaining three values.

Morphological, cultural, physiological and biochemical characteristics of strains $\mathrm{CM} 2104^{\mathrm{T}}$ and $\mathrm{CM} 2110$ are given in the species description (see below) and in Table 1, together with those of J. limosus and J. terrae. Strains $\mathrm{CM} 2104^{\mathrm{T}}$ and CM2110 contained meso-diaminopimelic acid as the diagnostic diamino acid in the cell wall. The predominant isoprenoid quinone was tetrahydrogenated menaquinone with eight isoprene units $\left[\mathrm{MK}-8\left(\mathrm{H}_{4}\right)\right]$. The major fatty acids of strains $\mathrm{CM} 2104^{\mathrm{T}}$ and CM2110 were iso- $\mathrm{C}_{16: 0}, \mathrm{C}_{17: 1} \omega 8 c$ and $\mathrm{C}_{18: 1} \omega 9 c$ or $\mathrm{C}_{17: 0}$ (Table 2). There were differences in the proportions of some fatty acids when the two strains were grown on solid $\mathrm{R}$ medium and TSA (Table 2). These cellular fatty acid profiles were similar to those of J. limosus DSM $11140^{\mathrm{T}}$ and J. terrae KCCM $80001^{\mathrm{T}}$, although there were differences in the proportions of some fatty acids. The cellular polar lipids found in the two strains were phosphatidylglycerol, diphosphatidylglycerol and phosphatidylinositol. The DNA G $+\mathrm{C}$ content of strains CM2104 ${ }^{\mathrm{T}}$ and CM2110 was $73 \mathrm{~mol} \%$.

Almost complete 16S rRNA gene sequences of strains $\mathrm{CM} 2104^{\mathrm{T}}$ and $\mathrm{CM} 2110$ comprised $1479 \mathrm{nt}$, corresponding to positions 28 and 1524 of the Escherichia coli 16S rRNA gene sequence. The 16S rRNA gene sequences of strains $\mathrm{CM} 2104^{\mathrm{T}}$ and $\mathrm{CM} 2110$ differed in four positions $(0.3 \%$ difference). Sequence comparison revealed that the two strains had the highest 16S rRNA gene sequence similarity to members of the family Intrasporangiaceae, particularly to the genus Janibacter. The sequences of strains CM $2104^{\mathrm{T}}$ and CM2110 contained 32 signature nucleotides associated with the family Intrasporangiaceae (Stackebrandt \& Schumann, 2000). The two sequences contained 28 of 29 signature nucleotides defined for the genus Janibacter as described by Maszenan et al. (2000); the two strains had the matching base pair G-C at positions 140-223 instead of G-T or A-T as given by Maszenan et al. (2000). In the neighbour-joining phylogenetic tree based on $16 \mathrm{~S}$ rRNA gene sequences, strains $\mathrm{CM} 2104^{\mathrm{T}}$ and CM2110 formed a coherent cluster, which was supported by a bootstrap resampling value of $100 \%$, and joined the phylogenetic clade comprising J. limosus and J. terrae (Fig. 1). This tree topology was also found in the tree generated with the maximum-parsimony algorithm (data not shown). Strains CM2104 ${ }^{\mathrm{T}}$ and CM2110 exhibited 16S rRNA gene sequence similarity levels of $97 \cdot 8-98 \cdot 4 \%$ to J. limosus DSM $11140^{\mathrm{T}}$ and J. terrae KCCM $80001^{\mathrm{T}}, 96 \cdot 9-98 \cdot 0 \%$ to Knoellia sinensis DSM $12331^{\mathrm{T}}$ and Knoellia subterranea DSM $12332^{\mathrm{T}}$ and less than $97 \cdot 0 \%$ 
Table 1. Phenotypic characteristics of J. limosus, J. terrae and Janibacter melonis sp. nov.

Data for reference species were taken from Martin et al. (1997) (J. limosus) or Yoon et al. (2000) and Lang et al. (2003) (J. terrae). +, Positive; -, negative; W, weakly positive; ND, not determined. Data in parentheses are for the type strain. All species were positive for Gram-stain, catalase, hydrolysis of casein, starch and Tween 80, utilization of DL-malate, nitrate reduction and growth in the presence of 2, 4 and $6 \% \mathrm{NaCl}$. All species were negative for spore formation, motility, hydrolysis of urea, production of indole, Voges-Proskauer and methyl red reactions, and acid production from L-arabinose, D-cellobiose, D-fructose, D-galactose, D-glucose, lactose, maltose, D-mannitol, Dmannose, D-raffinose, L-rhamnose, D-ribose, D-sorbitol, D-trehalose and D-xylose.

\begin{tabular}{|c|c|c|c|}
\hline Characteristic & J. limosus & J. terrae & J. melonis \\
\hline Morphology & Cocci, rods & Cocci or short rods & Cocci \\
\hline $\mathrm{H}_{2} \mathrm{~S}$ production & + & $\mathrm{v}(+)$ & - \\
\hline \multicolumn{4}{|l|}{ Hydrolysis of: } \\
\hline Aesculin & - & - & + \\
\hline \multicolumn{4}{|l|}{ Utilization of: } \\
\hline Acetate & $\mathrm{v}(+)$ & $\mathrm{v}(+)$ & + \\
\hline Benzoate & - & $\mathrm{v}(+)$ & - \\
\hline Citrate & + & $-(\mathrm{ND})$ & + \\
\hline Formate & + & $\mathrm{V}(\mathrm{ND})$ & + \\
\hline $10 \% \mathrm{NaCl}(\mathrm{R}$ medium $)$ & + & $(-)$ & - \\
\hline $10 \% \mathrm{NaCl}$ (BHI medium) & - & + & - \\
\hline \multicolumn{4}{|l|}{ Growth on $\mathrm{R}$ medium at: } \\
\hline $37^{\circ} \mathrm{C}$ & - & + & + \\
\hline $40^{\circ} \mathrm{C}$ & - & + & - \\
\hline \multicolumn{4}{|l|}{ Growth on BHI medium at: } \\
\hline $37^{\circ} \mathrm{C}$ & + & $(+)$ & + \\
\hline $40{ }^{\circ} \mathrm{C}$ & - & $(-)$ & + \\
\hline
\end{tabular}

to other species (Fig. 1). The mean level of DNA-DNA relatedness between strains $\mathrm{CM} 2104^{\mathrm{T}}$ and $\mathrm{CM} 2110$ was $89 \%$, when each of their DNAs was separately used as labelled DNA probe. Strains CM2104 ${ }^{\mathrm{T}}$ and CM2110 exhibited levels of DNA-DNA relatedness of $7-10 \%$ and $7-11 \%$ to J. limosus DSM $11140^{\mathrm{T}}$ and J. terrae KCCM $80001^{\mathrm{T}}$, respectively.

Strains $\mathrm{CM} 2104^{\mathrm{T}}$ and $\mathrm{CM} 2110$ are representatives of bacteria that cause abnormal spoilage in oriental melon, which results in great economic losses in melon cultivation. Detailed data regarding the abnormal spoilage caused by strains $\mathrm{CM} 2104^{\mathrm{T}}$ and $\mathrm{CM} 2110$ will be published elsewhere. It may be important to determine the exact taxonomic positions of strains $\mathrm{CM} 2104^{\mathrm{T}}$ and $\mathrm{CM} 2110$ for rapid identification and diagnosis of these isolates. The result of $16 \mathrm{~S}$ rRNA gene sequence analysis showed that strains $\mathrm{CM} 2104^{\mathrm{T}}$ and CM2110 exhibited closest phylogenetic affiliation to the genus Janibacter (Fig. 1). Chemotaxonomic data obtained from the strains were also most similar to those of the genus Janibacter (Stackebrandt \& Schumann, 2000; Yoon et al., 2000; Groth et al., 2002). The mesodiaminopimelic acid type clearly distinguished strains
$\mathrm{CM} 2104^{\mathrm{T}}$ and $\mathrm{CM} 2110$ from members of the genus Ornithinicoccus, which contain L-ornithine, and the other genera of the Intrasporangiaceae, namely Intrasporangium, Terrabacter and Terracoccus, which contain LL-diaminopimelic acid (Groth et al., 1999; Stackebrandt \& Schumann, 2000). Differences in major fatty acid contents also distinguished strains CM2104 ${ }^{\mathrm{T}}$ and CM2110 from members of the genera Ornithinicoccus, Intrasporangium, Terrabacter and Terracoccus, which contain iso- $\mathrm{C}_{15: 0}$ as the major fatty acid, and the genus Knoellia, which contain unsaturated fatty acids (particularly $\mathrm{C}_{17: 1}$ and $\mathrm{C}_{18: 1}$ ) as minor components (Groth et al., 1999, 2002; Maszenan et al., 2000; Yoon et al., 2000) (Table 2). In comparison with Tetrasphaera, strains CM2104 ${ }^{\mathrm{T}}$ and CM2110 differed in the amounts of anteiso-branched fatty acids, which were minor components in strains CM2104 ${ }^{\mathrm{T}}$ and $\mathrm{CM} 2110$ and comprised more than $32 \%$ in the genus Tetrasphaera (Maszenan et al., 2000; Hanada et al., 2002). Accordingly, both phylogenetic and chemotaxonomic data indicate that strains $\mathrm{CM} 2104^{\mathrm{T}}$ and CM2110 are members of the genus Janibacter.

Strains $\mathrm{CM} 2104^{\mathrm{T}}$ and CM2110 showed almost identical phenotypic characteristics, except growth in liquid BHI 
Table 2. Percentage cellular fatty acid compositions of J. limosus DSM $11140^{\top}$, J. terrae KCCM $80001^{\top}$ and strains $\mathrm{CM} 2104^{\mathrm{T}}$ and $\mathrm{CM} 2110$ collected from solid R medium and TSA

Data for J. limosus and J. terrae were taken from Yoon et al. (2000). Fatty acids that represent less than $0.5 \%$ in all rows were omitted. -, Not detected.

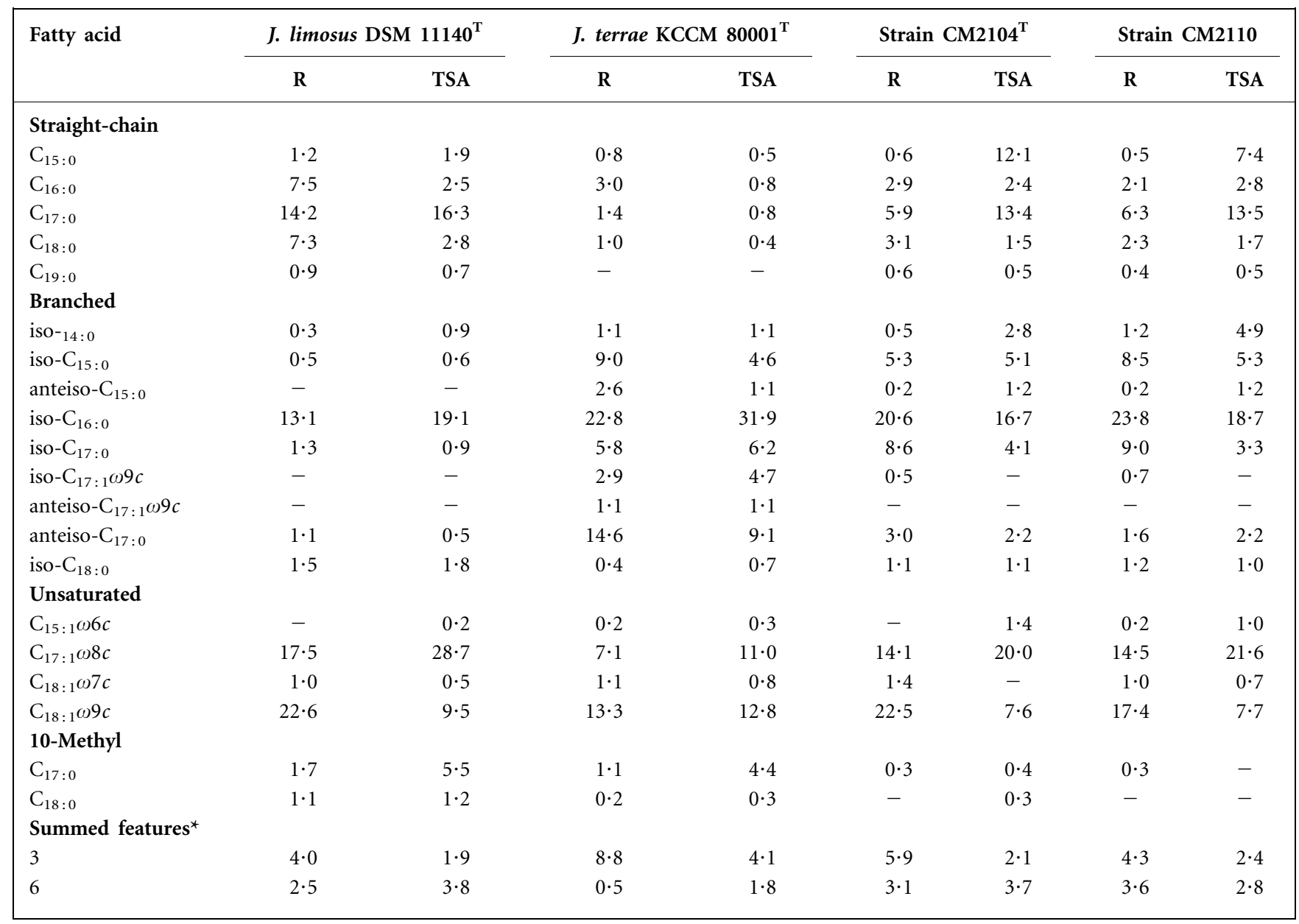

${ }^{\star}$ Summed features represent groups of two or three fatty acids that could not be separated by GLC with the MIDI system. Summed feature 3 contained iso- $\mathrm{C}_{15: 0} 2-\mathrm{OH}$ and/or $\mathrm{C}_{16: 1} \omega 7 c$. Summed feature 6 contained $\mathrm{C}_{19: 1} \omega 9 c$ and/or $\mathrm{C}_{19: 1} \omega 11 c$.

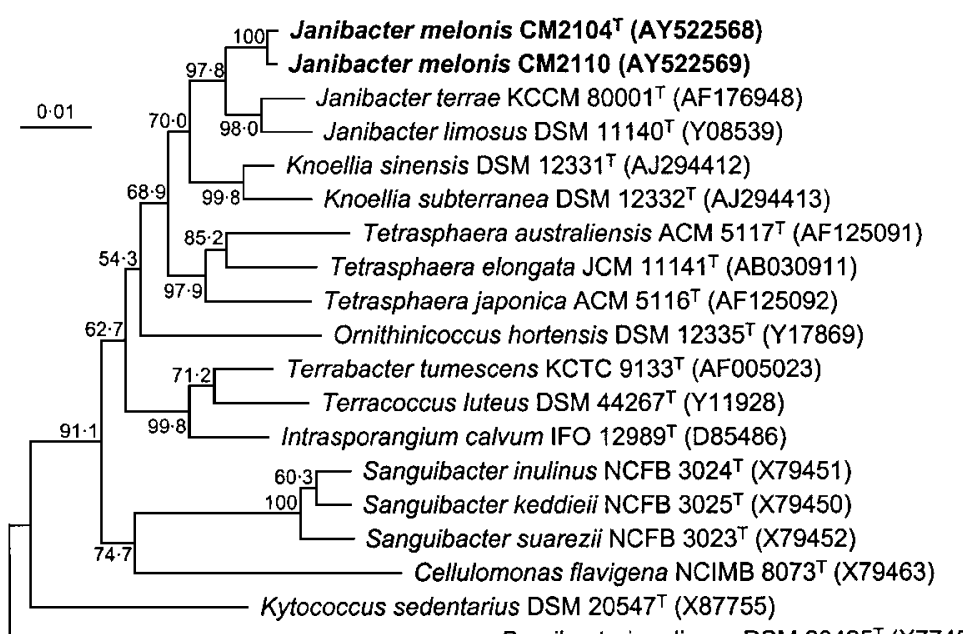

Brevibacterium linens DSM $20425^{\top}(X 77451)$
Fig. 1. Neighbour-joining tree showing the phylogenetic positions of strains CM2104 and CM2110, Janibacter species and some other related taxa based on 16S rRNA gene sequences. Bar, 0.01 substitutions per nucleotide position. Bootstrap values (expressed as percentages of 1000 replications) greater than $50 \%$ are shown at the branching points. 
medium and hydrolysis of casein (Table 1). The two strains were also phylogenetically similar, showing four nucleotide differences $(0.3 \%$ difference) in their $16 \mathrm{~S}$ rRNA gene sequences (Fig. 1). DNA-DNA relatedness indicates that strains CM2104 ${ }^{\mathrm{T}}$ and CM2110 are members of the same genomic species (Wayne et al., 1987). Strains CM2104 ${ }^{\mathrm{T}}$ and CM2110 are differentiated from other Janibacter species by several physiological characteristics, such as temperature for growth, $\mathrm{NaCl}$ tolerance and hydrolysis of certain substrates (Table 1). DNA-DNA relatedness values between strains CM2104 ${ }^{\mathrm{T}}$ and CM2110 and the type strains of two Janibacter species were far below the threshold value $(70 \%)$ suggested for species delineation in current bacterial systematics (Wayne et al., 1987). Genomic distinctiveness, together with differential phenotypic properties and $16 \mathrm{~S}$ rRNA gene sequence similarity data, justify a taxonomic discrimination of strains CM2104 ${ }^{\mathrm{T}}$ and CM2110 from the two accepted Janibacter species. Therefore, on the basis of the data presented, strains $\mathrm{CM} 2104^{\mathrm{T}}$ and $\mathrm{CM} 2110$ should be placed in the genus Janibacter as members of a novel species, for which the name Janibacter melonis sp. nov. is proposed.

\section{Description of Janibacter melonis sp. nov.}

Janibacter melonis [me.lo'nis. L. gen. n. melonis of melon (Cucumis melo), referring to the fruit from which the organisms were isolated].

Cells are aerobic, non-spore-forming, non-motile cocci, $0 \cdot 8-1 \cdot 0 \mu \mathrm{m}$ in diameter. Gram-positive. Non-acid-fast. Colonies are smooth, circular, convex, glistening, creamcoloured and $1.5-3.0 \mathrm{~mm}$ in diameter after 7 days incubation on solid R medium; those of the type strain wrinkle as cultures age. Neither substrate nor primary mycelium is formed. Optimal temperature for growth is $30^{\circ} \mathrm{C}$. Grows occurs at $10{ }^{\circ} \mathrm{C}$ but not at $4{ }^{\circ} \mathrm{C}$. Grows occurs at $40^{\circ} \mathrm{C}$ in liquid $\mathrm{BHI}$ medium but not in liquid $\mathrm{R}$ medium. Optimal $\mathrm{pH}$ for growth is around $7 \cdot 0$; growth occurs at $\mathrm{pH} 5 \cdot 5$ but not at $\mathrm{pH} 5 \cdot 0$. Tweens 20,40 and 60 and tyrosine are hydrolysed. Hypoxanthine and xanthine are not hydrolysed. Acid is not produced from adonitol, myo-inositol, D-melezitose, melibiose or sucrose. The cell-wall peptidoglycan contains meso-diaminopimelic acid as the diagnostic diamino acid. The predominant menaquinone is MK$8\left(\mathrm{H}_{4}\right)$. The major fatty acids are iso- $\mathrm{C}_{16: 0}, \mathrm{C}_{17: 1} \omega 8 c$ and $\mathrm{C}_{18: 1} \omega 9 c$ or $\mathrm{C}_{17: 0}$. The cellular polar lipids are phosphatidylglycerol, diphosphatidylglycerol and phosphatidylinositol. The DNA G $+\mathrm{C}$ content is $73 \mathrm{~mol} \%$ (determined by HPLC). Other characteristics are given in Table 1.

The type strain, CM2104 ${ }^{\mathrm{T}}\left(=\mathrm{KCTC} 9987^{\mathrm{T}}=\mathrm{DSM} 16063^{\mathrm{T}}\right.$ $=\mathrm{JCM} 12321^{\mathrm{T}}$ ), was isolated from the inner part of abnormally spoiled oriental melon in Korea.

\section{Acknowledgements}

J.-H.Y. and H. B. L. contributed equally to this work. This work was supported by the 21C Frontier programme of Microbial Genomics and Applications (grant MG02-0401-001-1-0-0) from the Ministry of Science and Technology (MOST) of the Republic of Korea.

\section{References}

Cowan, S. T. \& Steel, K. J. (1965). Manual for the Identification of Medical Bacteria. London: Cambridge University Press.

Ezaki, T., Hashimoto, Y. \& Yabuuchi, E. (1989). Fluorometric deoxyribonucleic acid-deoxyribonucleic acid hybridization in microdilution wells as an alternative to membrane filter hybridization in which radioisotopes are used to determine genetic relatedness among bacterial strains. Int J Syst Bacteriol 39, 224-229.

Felsenstein, J. (1981). Evolutionary trees from DNA sequences: a maximum likelihood approach. J Mol Evol 17, 368-376.

Felsenstein, J. (1993). PHYLIP: Phylogenetic Inference Package, version 3.5. Distributed by the author. Department of Genetics, University of Washington, Seattle, USA.

Gordon, R. E. \& Mihm, J. M. (1957). A comparative study of some strains received as nocardiae. J Bacteriol 73, 15-27.

Groth, I., Schumann, P., Martin, K., Schuetze, B., Augsten, K., Kramer, I. \& Stackebrandt, E. (1999). Ornithinicoccus hortensis gen. nov., sp. nov., a soil actinomycete which contains L-ornithine. Int J Syst Bacteriol 49, 1717-1724.

Groth, I., Schumann, P., Schütze, B., Augsten, K. \& Stackebrandt, E. (2002). Knoellia sinensis gen. nov., sp. nov. and Knoellia subterranea sp. nov., two novel actinobacteria isolated from a cave. Int J Syst Evol Microbiol 52, 77-84.

Hanada, S., Liu, W.-T., Shintani, T., Kamagata, Y. \& Nakamura, K. (2002). Tetrasphaera elongata sp. nov., a polyphosphate-accumulating bacterium isolated from activated sludge. Int J Syst Evol Microbiol 52, 883-887.

Hugh, R. \& Leifson, E. (1953). The taxonomic significance of fermentative versus oxidative metabolism of carbohydrates by various Gram negative bacteria. J Bacteriol 66, 24-26.

Imamura, Y., Ikeda, M., Yoshida, S. \& Kuraishi, H. (2000). Janibacter brevis sp. nov., a new trichloroethylene-degrading bacterium isolated from polluted environments. Int J Syst Evol Microbiol 50, 1899-1904.

Jukes, T. H. \& Cantor, C. R. (1969). Evolution of protein molecules. In Mammalian Protein Metabolism, vol. 3, pp. 21-132. Edited by H. N. Munro. New York: Academic Press.

Kluge, A. G. \& Farris, F. S. (1969). Quantitative phyletics and the evolution of anurans. Syst Zool 18, 1-32.

Komagata, K. \& Suzuki, K. (1987). Lipids and cell-wall analysis in bacterial systematics. Methods Microbiol 19, 161-203.

Lang, E., Kroppenstedt, R. M., Swiderski, J., Schumann, P., Ludwig, W., Schmid, A. \& Weiss, N. (2003). Emended description of Janibacter terrae, including ten dibenzofuran-degrading strains and Janibacter brevis as its later heterotypic synonym. Int J Syst Evol Microbiol 53, 1999-2005.

Lanyi, B. (1987). Classical and rapid identification methods for medically important bacteria. Methods Microbiol 19, 1-67.

Martin, K., Schumann, P., Rainey, F. A., Schuetze, B. \& Groth, I. (1997). Janibacter limosus gen. nov., sp. nov., a new actinomycete with meso-diaminopimelic acid in the cell wall. Int J Syst Bacteriol 47, 529-534.

Maszenan, A. M., Seviour, R. J., Patel, B. K. C., Schumann, P., Burghardt, J., Tokiwa, Y. \& Stratton, H. M. (2000). Three isolates of novel polyphosphate-accumulating Gram-positive cocci, obtained from activated sludge, belong to a new genus, Tetrasphaera gen. nov., and description of two new species, Tetrasphaera japonica sp. nov. and Tetrasphaera australiensis sp. nov. Int J Syst Evol Microbiol 50, 593-603.

Minnikin, D. E., O'Donnell, A. G., Goodfellow, M., Alderson, G., Athalye, M., Schaal, A. \& Parlett, J. H. (1984). An integrated 
procedure for the extraction of bacterial isoprenoid quinones and polar lipids. J Microbiol Methods 2, 233-241.

Saitou, N. \& Nei, M. (1987). The neighbor-joining method: a new method for reconstructing phylogenetic trees. Mol Biol Evol 4, 406-425.

Sasser, M. (1990). Identification of Bacteria by Gas Chromatography of Cellular Fatty Acids. Newark, DE: MIDI Inc.

Stackebrandt, E. \& Schumann, P. (2000). Description of Bogoriellaceae fam. nov., Dermacoccaceae fam. nov., Rarobacteraceae fam. nov. and Sanguibacteraceae fam. nov. and emendation of some families of the suborder Micrococcineae. Int J Syst Evol Microbiol 50, 1279-1285.

Tamaoka, J. \& Komagata, K. (1984). Determination of DNA base composition by reverse-phase high-performance liquid chromatography. FEMS Microbiol Lett 25, 125-128.

Thompson, J. D., Higgins, D. G. \& Gibson, T. J. (1994). ClUSTAL W: improving the sensitivity of progressive multiple sequence alignment through sequence weighting, position-specific gap penalties and weight matrix choice. Nucleic Acids Res 22, 4673-4680.
Wayne, L. G., Brenner, D. J., Colwell, R. R. \& 9 other authors (1987). Report of the ad hoc committee on reconciliation of approaches to bacterial systematics. Int J Syst Bacteriol 37, 463-464.

Yoon, J.-H., Kim, H., Kim, S.-B., Kim, H.-J., Kim, W. Y., Lee, S. T., Goodfellow, M. \& Park, Y.-H. (1996). Identification of Saccharomonospora strains by the use of genomic DNA fragments and rRNA gene probes. Int J Syst Bacteriol 46, 502-505.

Yoon, J.-H., Lee, S. T. \& Park, Y.-H. (1998). Inter- and intraspecific phylogenetic analysis of the genus Nocardioides and related taxa based on 16S rDNA sequences. Int J Syst Bacteriol 48, 187-194.

Yoon, J.-H., Lee, K.-C., Kang, S.-S., Kho, Y. H., Kang, K. H. \& Park, Y.-H. (2000). Janibacter terrae sp. nov., a bacterium isolated from soil around a wastewater treatment plant. Int J Syst Evol Microbiol 50, 1821-1827.

Yoon, J.-H., Kim, I.-G., Kang, K. H., Oh, T.-K. \& Park, Y.-H. (2003). Bacillus marisflavi sp. nov. and Bacillus aquimaris sp. nov., isolated from sea water of a tidal flat of the Yellow Sea in Korea. Int J Syst Evol Microbiol 53, 1297-1303. 